\title{
Administration and Faculty Perceptions (in an Online Post-Secondary Institution) of Whether Students Are Purely Students, Customers, or Both
}

\author{
Marguerite E. Barta \\ Kaplan University, Davenport, IA, USA
}

mbarta@kaplan.edu

\begin{abstract}
This paper explores whether students are customers, students, or both students and customers. The following are discussed: How do administrative members (deans, assistant deans, chairs, assistant chairs), full-time faculty, and adjunct faculty members within an online post-secondary learning institution perceive their students' status within the organization? Are the students purely students, or are the students also customers? What paradigm exists within the minds of the administrative members and faculty members? If the students are purely students, then is the online post-secondary learning institution purely a function of scholarly excellence? Conversely, if the students are customers, then is the online post-secondary learning institution predominantly a business that is selling a product and must go to great lengths to keep the e-customer happy? What are the perceptions of administration and faculty? Are the students purely students, or are the students also customers? Furthermore, if the online post-secondary learning institution recognizes that there are, indeed, customers, is it sure that the students are the customers? Perhaps some administrative members and faculty members consider the customers to be the final consumers of the product, so consideration of whether the students are purely students or whether the students are customers is moot.
\end{abstract}

Keywords: student, customer

\section{Introduction}

This qualitative, virtual, ethnographic paper explored the perceptions of administrative members (deans, assistant deans, chairs, and assistant chairs); full-time faculty; and adjunct faculty members at an online post-secondary learning institution to identify whether the students are purely students, whether the students are customers, whether the students are students and customers, or whether the customers/consumers exist outside of the learning institution.

Material published as part of this publication, either on-line or in print, is copy righted by the Informing Science Institute. Permission to make digital or paper copy of part or all of these works for personal or classroom use is granted without fee provided that the copies are not made or distributed for profit or commercial advantage AND that copies 1) bear this notice in full and 2) give the full citation on the first page. It is permissible to abstract these works so long as credit is given. To copy in all other cases or to republish or to post on a server or to redistribute to lists requires specific permission and payment of a fee. Contact Publisher@InformingScience.org to request redistribution permission.

\section{Study}

Twenty-six respondents participated in an e-interview in which they were asked to describe the university's current state of customer-centricity/student centricity. This request immediately triggered new considerations/questions: Are the students customers? Are the students just students, and not customers? Are the 
students customers and students? If the students are not customers, then who are the customers? If there are customers, then there must be a product. Businesses sell products to generate revenue. Therefore, who are the final customers, and who consume the product of the university? Is the university a business? Does the university produce a product? If the university does produce and sell a product, what is the product, and is that product tangible or intangible? What does the university sell? Does the university sell know ledge, which is an intangible product, or does it sell people, who are a tangible product that has been enhanced by the university? Are the students a raw product that the university adds "utility" to, and is the final product the graduating students, who have an enhanced value to the community and the business world by virtue of their education?

These questions provided for a considerable amount of conversation. This report presents the results to the statement that asked the 26 respondents to describe the university's current state of customer-centricity/student centricity by identifying whether the students are purely students, whether the students are customers, whether the students are students and customers, or whether the customers/consumers exist outside of the learning institution.

\section{Results}

\section{The Students Are Not Customers}

The students are not customers (the students are students), and the university is not a business in the traditional sense of the word; therefore, for the purpose of our discussion, one must consider student-centricity as opposed to customer-centricity. A university provides education and is philanthropic in nature. A university provides a service to the community, to the country, to the world, and to the people. The university is not a business because the university makes money to sustain itself, not to add to the bottom line. Although there may be times when a university does have a healthy bottom line, the goal of the university is to educate the masses, and the healthy bottom line is a byproduct of the act of education. If the university is not a business, then the university cannot have customers in the purest sense of the word. The university has students, and the students are not customers (Respondents A, B, E, F, J, R, \& U).

\section{The Students Are Customers}

The students are customers (Respondents $\mathrm{G}, \mathrm{K}, \& \mathrm{Z}$ ), and the university is a business in the traditional sense of the word; therefore, for the purpose of our discussion, we must consider customercentricity as opposed to student-centricity. In the case of this university, one of the goals of the university is to make money (Respondent B). The method for making money is to manage the delivery of knowledge. Knowledge is used to add utility to the student. The student is the final consumer of knowledge; therefore, the student is a customer. The university generates revenue by recruiting students to purchase the university's delivery of knowledge. In the end, the university is a business; the university provides an intangible product; and although the product of the university may be altruistic, the final goal is to make money, generate revenue, and create profit.

\section{The Student Are Students and Customers}

The students are both students and customers, and the university is a business, but not a business; therefore, the concepts of customer-centricity and student-centricity are one in the same (Respondents A, B, C, D, M, P, \& Q). Yes, the students are students because they are at the university to learn, but the students also are customers because the university markets itself; the university advertises its services; the university actively recruits students; the university works diligently to provide a product, the delivery of know ledge, which will be of value to the students; and the uni- 
versity works diligently to retain the students (Respondent E). All of these are all actions of a business. Although the money taken in as revenue by the university is labeled tuition, tuition is the price that the student's pay. It also is the method that the university uses to gather revenue, which ultimately becomes profit. Once the students leave the university, the institution loses not only are the students but also the customers. The opportunity for the university to generate revenue is gone. Therefore, it may be posited that the university is a business, and not a business. When the university speaks of students, the university is not a business, but when the university speaks of consumers or customers, then the university is a business.

\section{Students Are Products, and the University Is an Intermediary That Adds Utility to the Product (Students)}

The most interesting perspective is that the university is an intermediary. Within a business "channel of distribution" is the raw product (i.e., people who are recruited by the university); the manufacturing process (i.e., the act of adding utility to the raw product); and a new consumable product (i.e., university graduates). Finally, the consumable product is delivered to the marketing intermediaries (i.e., the middlemen), the agents and brokers who bring the buyers and sellers together. In this case, the marketing intermediaries are the headhunters, the employment agencies, Monster.com, and the classifieds that facilitate the delivery of the consumable product (i.e., the graduates) to the retailers. The retailers are the businesses or institutions that sell the product/consumable, which is representative of value, ultimately to the consumers. In this sense, the educated students are the entities who provide an intangible service that is sold to the consumers. The consumers are the person who contract with businesses to purchase something of value. These items would not be available to the final consumers if the retailers did not obta in the trained students/persons to perform the required tasks, which translate into value for the final consumers. Therefore, the students are the deliverable that moves through the channel of distribution, and the university is an intermediary. The university simply adds utility to the de liverable.

\section{Conclusion}

This qualitative virtual ethnographic paper explored the perceptions of administrative members (deans, assistant deans, chairs, and assistant chairs); full-time faculty; and adjunct faculty members at an online post-secondary learning institution to identify whether the students are purely students, whether the students are customers, whether the students are students and customers, or whether the customers/consumers exist outside of the learning institution.

\section{Biography}

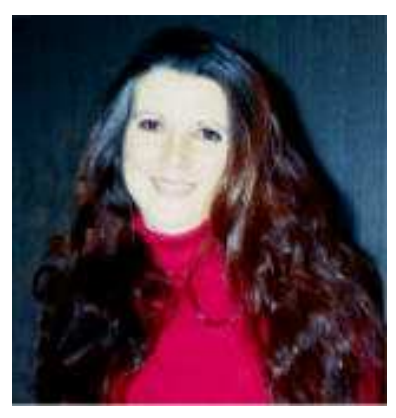

Dr. Barta's research focus is cybergogy. The Internet has fostered an environment where information is obsolete before it is even created, and this same environment of information obsolescence rules the world of online learning and cybergogy. Cyberspace has created a vast panorama of opportunity for online education, and Dr. Barta's research explores online learning and cybergogy. It is with this in mind that Dr. Barta presents a paper entitled, "Administration and Faculty Perceptions (in an Online Post-Secondary Institution) of Whether Students Are Purely Students, Customers, or Both.” Dr. Barta earned a Ph.D. in organization and management, $w$ ith a specialization in E-business. Dr. Barta holds two graduate degrees, one in managerial leadership and one in E-business. Finally, Dr. Barta has an undergraduate degree in bus iness management. Dr. Barta is a full-time faculty member in the School of Business for Kaplan University. In the winter of 2009, Dr. Barta was 
Administration and Faculty Perceptions

awarded the nomination for professor of the year, as a representative of the School of Business, Kaplan 